\title{
CIRCULAÇÃO DE IMAGENS FOTOGRÁFICAS DE PAISAGENS RURAIS: COMUNICAÇÃO, MARKETING E ATRAÇÃO DE DEMANDA
}

\author{
ANDRÉ RIANI COSTA PERINOTTO \\ Universidade Federal do Piauí, Campus Ministro Reis Velloso \\ Parnaíba, Piauí, Brasil \\ E-mail: perinotto@ufpi.edu.br
}




\section{CIRCULAÇÃO DE IMAGENS FOTOGRÁFICAS DE PAISAGENS RURAIS: COMUNICAÇÃO, MARKETING E ATRAÇÃO DE DEMANDA}

Resumo: O objetivo do estudo foi descrever, e averiguar, a importância da circulação de imagens fotográficas em distintas mídias para a promoção, divulgação e atração de potenciais demandas reprimidas ou reais/potenciais. Assim, propõe-se passear por entre as imagens fotográficas em diferentes mídias, para conhecer e se aproximar da realidade de cada localidade que se pretende comunicar turisticamente, ainda mais em paisagens rurais. Desse modo, cartografando a circulação como um flâneur em trânsito por diferentes mídias.

Palavras-chave: Comunicação; Turismo; Imagens Fotográficas; Paisagem Rural

\section{LA CIRCULACIÓN DE LAS IMÁGENES FOTOGRÁFICAS DE PAISAJES RU- RALES: LA COMUNICACIÓN, EL MARKETING Y LA ATRACCIÓN DE LA DEMANDA}

Resumen: El objetivo del estudio fue describir y determinar la importancia de la circulación de las imágenes fotográficas en diferentes medios de comunicación para la promoción, la difusión y la atracción de posibles reclamaciones reprimido o reales / potencial. Por lo tanto, se propone dar un paseo entre las imágenes fotográficas en diferentes medios de comunicación, de conocer y acercarse a la realidad de cada lugar que que desea comunicarse turísticamente, más aún en los paisajes rurales. Por lo tanto, trazar el movimiento como un flâneur en tránsito a través de diferentes medios.

Palabras clave: Comunicación; Turismo; Imágenes fotográficas; Paisaje rural

\section{CIRCULATION OF PHOTOGRAPHIC IMAGES OF RURAL LANDSCAPES: COMMUNICATION, MARKETING AND ATTRACTION OF DEMAND}

Abstract: The study objective was to describe and determine the importance of the circulation of photographic images in different media for the promotion, dissemination and attracting potential repressed or actual / potential claims. Thus, it is proposed to stroll amongst photographic images in different media, to meet and get closer to the reality of each location that you want to touristic communicate, more so in rural landscapes. Thus, charting the movement as a flâneur in transit through different media.

Keywords: Communication; Tourism; Images Photographs; Rural Landscape 


\section{INTRODUÇÃO}

O problema de pesquisa, que culminou nesse artigo, surgiu através de observações de processos midiático-comunicacionais nas mídias com imagens fotográficas do meio rural e de leituras de diversos textos sobre a relação da circulação midiática e a imagem fotográfica turística. Surgiu, também, de certa da percepção da "falta" de comunicação turística mais efetiva, capaz de "vender" e "apresentar" a paisagem e a localidade no meio rural para "o mundo", bem como, da carência de circulação da imagem fotográfica dessas paisagens em diferentes mídias. Basicamente, esta foi a situação indeterminada da qual partimos e o que motivou a investigação.

Vale ressaltar que o turismo depende muito da comunicação, seja para comunicar o atrativo, seja para a comunicação entre empresas, entre outros fatores. Em termos tecnológicos e midiáticos, a comunicação turística se dá de diversas formas, seja por mídias impressas, televisão, rádio, Internet, entre outros. Ao variar as mídias e os aparatos tecnológicos, as localidades/atrativos podem ser comunicadas aos diferentes visitantes/turistas. Assim, o tema comunicação e turismo foi um dos fatores trabalhados e discutidos também aqui.

O objetivo desse artigo ficou no âmbito de descrição e averiguação da relevância da circulação de imagens fotográficas e como se deve, ou deveria ser, o trabalho de comunicação turística para atração de demandas. É importante lembrar que se trabalhou a circulação das imagens turísticas, uma vez que acredita-se que as imagens fotográficas em circulação possam atingir diversos e diferentes públicos que tenham acesso a determinadas mídias distintas (sejam elas: cartão postal, folder, a Internet, entre outros) ocorrendo assim uma comunicação turística através da fotografia. A Internet, nesse caso, funcionaria como um dos espaços (ferramentas) de circulação, ou não, dessas imagens fotográficas, sendo postadas em diferentes espaços na rede, sites ou redes sociais.

Em um contexto geral, a problemática da pesquisa surgiu das observações, das vivências e experiências com um conjunto de objetos empíricos definidos, através de uma busca por referências bibliográficas que trouxessem como são trabalhadas a circulação, a imagem fotográfica turística no meio rural e a interação de comunicação, marketing e paisagens rurais. Portanto, a pesquisa se baseou em pesquisa bibliográfica e empírica para que se pudesse discutir essas temáticas no trabalho. 


\section{BREVE CONTEXTUALIZAÇÃO DO TURISMO NO ESPAÇO RURAL E A IMAGEM FOTOGRÁFICA IMPORTANTE PARA A COMUNICAÇÃO DE SUAS PAISAGENS.}

O turismo vem acendendo e obtendo novos lugares de práticas, dentre eles o espaço rural, que visa receber, principalmente, pessoas de grandes centros urbanos que, atraídas pela natureza e a simplicidade do campo, procuram paz, ar puro, belezas naturais (paisagens notáveis), atividades motoras, esportes radicais, e outras formas de promover o lazer e o entretenimento (Perinotto, 2008).

Várias práticas diferentes podem difundir-se no espaço rural, a saber: ecoturismo, turismo de aventura, turismo científico, pedagógico, de eventos e outros. Porém, o que mais atrai os turistas/demanda é a paisagem no meio rural, desse modo, ao trabalhar as imagens fotográficas das paisagens rurais passasse a tentativa de atrair demandas reprimidas (pelo desconhecimento dos destinos) ou reais/potenciais. Essa paisagem, através das imagens fotográficas, deve circular por diferentes mídias, para atrair essas demandas e trabalhar o marketing dessas localidades rurais.

Os principais segmentos do turismo no espaço rural estão ligados à tranquilidade e a observação da flora, da fauna e dos aspectos cênicos (paisagem), os estudos científicos e outros apelos que a demanda necessita.

Segundo Santos (1998 como citado em Perinotto, 2008), as atividades turísticas no espaço rural têm recebido uma infinidade de nomes. A EMBRATUR, em seu Manual Operacional de Turismo Rural (1994), conceitua o turismo rural como um turismo diferente, turismo de interior, turismo doméstico, turismo integrado, turismo endógeno, turismo alternativo, agroturismo e turismo verde.

O turismo rural não é concebido dentro dos padrões da hotelaria habitual. Ao contrário, tem um clima de informalidade e de absoluta familiaridade. "Cabe ressaltar que o turismo rural é o único segmento do turismo que não existe somente como atividade turística, mas sustenta-se em uma atividade quase tão antiga quanto à civilização, onde o produtor agrega a atividade turística às suas atividades tradicionais" (Castanheira, 2001).

Para Silva (1998 como citado em Perinotto, 2008), turismo no espaço rural englobaria a totalidade dos movimentos de lazer e turismo que se desenvolvem nesta área, denominadas de turismo rural, turismo ecológico, turismo de aventura, turismo cultural, turismo de saúde envolvendo spas 
rurais, centro de convenções (treinamento de executivos), trilhas, festivais, rodeios, camping, canoagem, pesca, caça etc.

Segundo Perinotto (2008) uma vivência no campo, talvez resuma em poucas palavras o que buscam as pessoas no turismo rural, em que praticam as atividades do cotidiano no campo, sem se preocupar, convivendo em paz com a natureza e o ar puro. Desse modo, a paisagem passar a vincular o que a demanda espera/necessita e as imagens fotográficas dessas paisagens. Para a divulgação e atração, na tentativa da tangibilidade dos produtos turísticos servidos no meio rural, é fundamental as imagens fotográficas e sua veiculação em distintas e diferentes mídias.

Desse modo, os registros fotográficos, segundo Santos Júnior e Santos (2007), possuem diversas funções que podem ser apropriadas no turismo, são elas: segmentação do mercado (fototurismo); elemento educacional (turistas e população local); como manifestação artística dos fotógrafos locais; mecanismo de marketing (cunho comercial); material de pesquisa de campo; registro histórico e ferramenta de planejamento e gestão. Frente a isso, o Turismo é um campo de estudo que necessita de um acervo material para levantar dados históricos e até mesmo geográficos, para construir um plano de ação com poder de gerar uma movimentação turística relevante.

Desse modo, Falco (2011 como citado em Perinotto, 2013b), a mídia é capaz de constar os lugares a serem induzidos como turísticos: por famílias em férias, por casais em lua-de-mel, por crianças, idosos etc. Cria-se, assim, uma espécie de cartografia turística, que irá designar locais atrativos nos mais diversos segmentos turísticos.

Com relação às fotografias impressas em material de mídia turística, De Botton (2005, p. 16 como citado em Perinotto, 2013b) afirma que "os responsáveis pelo folheto tinham tido a sinistra intuição de como transformar os leitores em presas fáceis por meio de fotografias cujo poder insultava a inteligência e desrespeitava toda e qualquer noção de livre arbítrio". Assim, o marketing poderia facilitar a demanda turística, através de imagens fotográficas e de paisagens que os produtores de folhetos/folders queriam e que muitas vezes não condiziam com a realidade local. Muitas vezes, a imagem que é passada no folheto/folder, é a imagem que os produtores escolhem a partir de seus produtos oferecidos. Uma questão interessante, ante o fato de que um de nossos observáveis é a mídia folder.

De acordo com Gastal (2005), a imagem para a atividade turística é voluntariamente mais importante do que os textos. Além do mais, com os 
avanços tecnológicos e a sua consequente popularização, permitiu-se que uma maior parcela de consumidores tivesse acesso às técnicas de manipulação de imagens, através das máquinas fotográficas e softwares de computadores. À vista disso, a atual civilização da imagem contradiz aquilo que Urry (1996, como citado em Perinotto, 2013b) afirmou "a câmera não mente", pois a câmera como instrumento é diferente do que acredita-se que seja imagem. Por essa razão, a representação de imagem fotográfica requer muito cuidado quando é veiculada nos cartões postais, folders, reportagens em jornais, revistas e em sites da Internet, para não ultrapassar os limites do que é "real".

Ainda, segundo Sontag (2004, p. 41), retrata sobre o embelezamento da fotografia "fotografar é atribuir importância. Provavelmente não existe tema que não possa ser embelezado; além disso, não há como suprimir a tendência, inerente a todas as fotos, de conferir valor a seus temas". Além disso, Sontag (2004, p. 106) apresenta uma visão sobre o modo como a câmera fotográfica pode interferir no olhar, ao se fazer (produzir) uma imagem fotográfica "[...] o tipo de beleza que só a câmera revela - um recanto de realidade material que o olho não enxerga normalmente ou não consegue isolar; ou a visão de cima, como a de um avião -, eis os alvos principais da conquista do fotógrafo".

Deste modo, as fotografias têm uma influência significativa na percepção de um destino turístico. Por isto, às vezes, a análise e a compreensão de alguns aspectos fundamentais que compõem a estrutura e composição de uma fotografia, significativa e de qualidade, tais como: temas, cores, iluminações, pessoas e equipamentos turísticos, que eventualmente são fotografados. Aqui cabe ressalvar, que embora seja importante apresentar diferentes olhares sobre a fotografia (sua importância, seus usos, sua história e as diversas reflexões sobre ela) nesses aspectos das imagens fotográficas, o nosso interesse maior foi sobre a circulação dessas imagens fotográficas nas diferentes mídias estudadas.

A aplicação da fotografia no turismo trouxe para mais perto um mundo visível de paisagens, culturas e lugares diversos. As fotografias utilizadas como registro de localidades e eventos, ou mesmo como um recurso de marketing turístico, passaram a ocupar um espaço substancial nas atividades do turismo. $O$ apelo realístico que as fotografias contêm facilita o esforço para decodificá-las ou lê-las. Além disso, a forma automática com que as fotografias são feitas contribui, de forma significativa, para a rapidez de 
sua produção. Assim, as fotografias podem passar a simular uma atualidade. Na fotografia turística está mais favorável para exprimir uma noção de informação, atualidade e similaridade no relato visual. Esses elementos, num nível instrumental, compõem um fazer fotográfico, em que é preconizado o papel fundamental da fotografia como útil para a informação do turismo no meio rural.

O turismo é uma atividade que pressupõe deslocamentos. Para que esses deslocamentos ocorram faz-se necessário criar mecanismos que estimulem o consumidor (turista/demanda) a evadir-se de seu local habitual e refugiar-se em um local que o tenha despertado, o interesse em conhecê-lo.

Assim, o turismo, principalmente o turismo no meio rural, é uma das atividades que mais utiliza a imagem para se promover e atrair turistas, pois o turista, antes de comprar um lugar, para desfrutar de suas férias, por exemplo, "compra" uma imagem, com um sonho ou um desejo.

Partindo desse pressuposto, Gândara (2008, p. 04) comenta que "a imagem é um elemento fundamental na estratégia de marketing de qualquer destino turístico". Assim, a imagem de um lugar quando retratada nas distintas mídias, pode mostrar a paisagem e a cultura de uma localidade, fazendo com que as pessoas se transportem para os locais que estão sendo ilustrados.

Diante disto, ao vender uma imagem de determinado local, não se deve pensar somente em agradar o cliente, com a finalidade de que a compra seja concretizada, mas também proporcionar um produto de qualidade, que venha realmente a satisfazer o turista.

O cliente pode definir qual lugar visitar, pela fotografia, focando em elementos característicos do local e facilitando a sua eleição, já que este já vem com uma imagem visual previamente criada no seu imaginário, diante das percepções e experiências prévias vivenciadas ao longo da sua decisão por viajar. Ou seja, se o turista, ao ser apresentado a um roteiro, ou lugar, que privilegia o cultural, este buscará encontrar um local que tenha como principal atividade elementos que incluam a diversidade cultural do local e o que esta venha a lhe proporcionar como novo e enriquecedor, no que tange a experiências que envolvam aspectos sociais, culturais, além de emocionais.

\section{CIRCULAÇÃO DAS IMAGENS FOTOGRÁFICAS TURÍSTICAS}

É importante salientar que é preciso compreender a circulação das imagens, além de perfilar quais as fotografias de paisagens turísticas se refor- 
çam e, assim, reconhecer os processos de comunicação turística, assim tratou-se sobre circulação midiática nos parágrafos abaixo.

Nesse sentido, podem-se focar as mudanças recentes das mídias e como se analisa suas funções atuais, como é o caso dos cartões postais - que sofreram alterações em sua função, pois tiveram diminuído seu consumo e alterado o uso para o qual foram criados, estando agora mais restritos a colecionadores (Perinotto, 2013a). Hoje, com a sociedade midiatizada e com o ambiente digital, as imagens fotográficas de antes (dos cartões postais) estão na rede. Desse modo, as pessoas para consumir o cartão postal necessitam viajar até o local e comprá-lo, pois raramente o receberão de alguém pelos correios, por exemplo. Com as fotografias digitais, as pessoas podem produzir suas imagens e imediatamente postá-las e compartilhá-las com seus contatos, diferentemente do cartão postal que precisa ser enviado via correio ou por transportadora.

Assim, atualmente, com as mídias em progresso e as suas funções mudando o tempo todo, consumimos várias mídias com lógicas distintas durante um mesmo dia, desde as mídias de massa às mídias de nicho - novos processos e ambientes de segmentação estão surgindo (Perinotto, 2013a). Para tanto, é necessária a articulação entre os diferentes tipos de mídia - novas formas de entrelaçamento (circulação). Buscou-se esse entrelaçamento, essa articulação existente, ou não, da comunicação turística nas distintas mídias a partir das imagens fotográficas constantes nas mídias para aprofundamento da comunicação turística, principalmente das paisagens no meio rural.

É interessante observar como a utilização de dispositivos permite o surgimento de novos processos de circulação, ao possibilitar fluxos comunicacionais que possam retornar, ocasionados assim pela geração de outros novos circuitos.

Desse modo, Fausto Neto (2010, p. 04) descreve que:

[...] a circulação deixa de ser um elemento "invisível” ou "insondável” e, graças a um trabalho complexo de linguagem técnica, segundo operações de dispositivos, explicita sua "atividade construcionista", gerando pistas, instituindo novos objetos e, ao mesmo tempo, procedimentos analíticos que ensejem a inteligibilidade do seu funcionamento e dos seus efeitos [...].

Fausto Neto (2010, p. 12), ainda, compreende o conceito de circulação, contribuindo para a nossa discussão sobre essa temática: 
[...] este deixa de ser um conceito associado à defasagem - ou simplesmente da diferença - e passa a ser compreendida como "ponto de articulação" entre produção e recepção. Avança como um novo objeto, pois a circulação é transformada em lugar no qual produtores e receptores se encontram em "jogos complexos" de oferta de reconhecimento. É nomeada como dispositivo que é levado em conta para realização do trabalho de negociação e de apropriação de sentidos, regidos por divergências e não por linearidades. Este esforço analítico se volta para formalizar um nível de existência da problemática da circulação, desta feita como um conceito que avança observações sobre a sua própria complexidade.

Interessante observar, nessa citação anterior, que a circulação é vista como um lugar em que produtores e receptores se encontram, como em no caso das imagens fotográficas que são postadas na Internet e se repetem algumas vezes, demonstrando essa complexidade e a não-linearidade dessa circulação, onde, por vezes, tais imagens se transpassam e se emaranham.

Seguindo essa linha de pensamento, comenta-se que a circulação não seria apenas um conceito que remeteria à noção de intervalo, mais que isso: é o âmbito de uma complexa articulação entre "prosperidades do discurso proposto e as estratégias de apropriações dos sujeitos" (Veron \& Levasseur, 1986 como citado em Fausto Neto, 2010, p. 12).

Uma forma bem sucinta e de fácil compreensão sobre o termo circulação, como comunicação baseada na interação social sobre a mídia que apresenta duas perspectivas: a econômica - trata-se da circulação de bens - e a circulação midiática - o que a mídia veicula (caracteriza-se como um sistema de produção).

Além disso, a circulação pode ser entendida como uma questão comunicacional a qual se baseia na perspectiva de uma comunicação através do diálogo que, segundo Ferreira (2010), é uma experiência social já superada, no mesmo processo em que há a mediação das interações sociais através de dispositivos. Ainda, Ferreira (2010) explica que a produção se transforma em consumidora, a qual se apropria de ofertas integradas a outros dispositivos, como parte importante da produção de seus próprios dispositivos e que sempre houve a relação entre os meios com a cultura. Além disso, seguindo o pensamento de Ferreira (2010), as características que compõem uma comunicação dialógica são:

A comunicação enquanto diálogo (conversa) é, enquanto experiência social, superada, no mesmo processo em que a linguagem 
passa a mediar as interações sociais, e, portanto, inscritas em dispositivos, passando essa a regular processos de comunicação diferida (no tempo e no espaço). [...] Em sociedades complexas, o que existe é a conversa midiatizada que busca reproduzir as características da conversa dialógica presencial, ou conversas presenciais que ocorrem no âmbito de paradigmas conversacionais midiatizados.

Há uma emergência de uma cultura da convergência, pois existem muitas mídias e muitos conteúdos - um ambiente plural que busca novas formas de integração. Novos formatos de redes midiáticas - da ênfase na convergência de máquinas/tecnologias para a convergência de conteúdos. Conteúdos que atravessam várias mídias - conteúdos e plataformas. A convergência como lógica de circulação de conteúdos nos novos ambientes digitais. É interessante ver que imagens de uma mesma paisagem (de um mesmo local) podem estar em diferentes mídias.

Atualmente, públicos consomem tecnologias e conteúdos da nova comunicação digital em diferentes níveis - mas todos estão expostos. Públicos internos e externos, locais e globais - impacto diferenciado na vida de pessoas e organizações. Porosidade das instituições/organizações nesse novo ambiente e relacionamento entre públicos - intensificação de trocas e relacionamentos com uma nova pauta cultural, pois há a produção de conteúdo nesse novo ambiente - uma pluralização de conteúdos (novas formas de pluralização). Assim, ocorre a lógica do compartilhamento - troca de textos, fotos, opiniões, entre outros, com o compartilhamento e colaboração.

Braga (2004) comenta que a sociedade midiatizada não é uma "consequência" dos dispositivos técnicos de mídia. Em sua abordagem, é a sociedade que gera essa necessidade, tratando-se da origem e desenvolvimento destas tecnologias midiáticas. Ainda:

[...] é porque a sociedade crescentemente gerou a necessidade, para processar suas interações, de comunicações mais amplas e abrangentes, mais específicas e especializadas, mais diversas, mais eficazes (etc.) que foi desenvolvendo mais e mais procedimentos e tecnologias mediáticas (Braga, 2004, p. 11).

Assim, para entender o processo de midiatização pelo viés da interação, ou seja, pela circulação, é preciso ver que o fluxo demanda uma nova visão, já não em termos de causa e consequência - perspectiva linear -, mas em termos de circularidade. $\mathrm{O}$ mesmo processo ocorre com a mediação, que 
implica movimento de significados, é circulação de significados para além de um fluxo de dois estágios (Silverstone, 2003, p. 33).

Não se pode esquecer que a digitalização das mídias pode fazer da Internet, dentre todas as mídias, a maior produtora de conteúdo e de circulação de imagem. Assim como ocorreu em outros mercados, além do mercado turístico, onde as tecnologias da informação e comunicação foram aplicadas, essa etapa pode eliminar muito esforço envolvido na produção da comunicação. Uma implicação da revolução da mídia digital é a convergência de meios de comunicação, como observa-se em alguns momentos. A multimídia está apagando as antigas distinções rígidas entre os meios de comunicação e o estudo da circulação observa muito isso. No atual mundo da mídia digital, as formas convencionais de mídia devem convergir e interagir, juntamente com outras formas híbridas, em um único meio.

Com o advindo da cultura digital, aumentam a capacidade de circulação e de conteúdos locais - novos circuitos (coisas locais circulando globalmente e vice-versa). Uma cultura de mobilidade do instantâneo e do relativo, onde, por exemplo, as imagens fotográficas do meio rural postadas na Internet poderão render novos circuitos, com novas ações, inclusive a de atrair a demanda.

Assim, quando se fala sobre circulação, vale ressaltar a importância dos circuitos na sua composição. Dessa forma, Braga (2012) comenta que o movimento da circulação ultrapassa a relação de emissão à recepção e, há, ainda, um segundo movimento de pós-recepção - “[...] a partir de reações deste subsistema 'de resposta social' (com suas mediações e 'desvios' interpretativos próprios) o fluxo comunicacional não para e um novo circuito, diferenciado, se inicia [...]" (Braga, 2012, p. 05), o que pode ou não fazê-lo retornar.

A circulação, também, é destacada por Fausto Neto (2001) como uma esfera de articulação, lugar constituinte da relação, no processo de comunicação. Assim, fazendo uma aproximação entre Braga e Fausto Neto, acredita-se que interessa para a comunicação, midiática ou não, a questão interacional como lugar de circulação entre oferta e consumo.

Em termos de circulação, mediante vivência na área de Turismo e em observações, por exemplo: um turista posta suas fotos de viagem na mídia de acesso, no caso a Internet, com a intenção de comunicar a mensagem de "eu já fui" ou "já estive lá"; depois disso, uma terceira pessoa pode ter acesso a esse site na Internet e, ao ter acesso a essas imagens fotográficas, acredita-se que poderá ser acionado a fazer novas investigações de outras mídias, buscando novas imagens, para, então, futuramente, quem sabe, realizar uma 
visita também (consumo), como turista, ao local fotografado e midiatizado.

De tal modo que se torna evidente, com o avanço da tecnologia, a troca de informações proporcionada pela Internet. Apresentando-se então novas formas de estabelecer uma comunicação, cada vez mais rápida e eficiente, que consegue atingir diversos públicos, mediante novos dispositivos como blogs e redes sociais, utilizados como fonte de circulação de imagens fotográficas, como em nosso caso.

Vale mencionar que a comunicação estabelece uma interação entre as pessoas por facilitar o acesso às informações e as trocas de experiências vivenciadas. Neste sentido, é válido argumentar sobre o valor comunicacional da circulação como forma de diálogo visual, em nosso caso, que, quando inscrito em dispositivos, media as interações sociais.

Deu-se ênfase sobre a discussão sobre a circulação das imagens fotográficas no meio rural, assim pensando na utilização de dispositivos como os cartões postais, os folders, revistas, jornais impressos, a Internet, entre outros, cada um com uma circulação distinta. Com a Internet, acredita-se que as imagens fotográficas recebam novo tratamento e são reenviadas no sistema mais amplo, que pode abranger os demais.

Assim, começa-se a observar uma visão de fluxo comunicacional capaz de perceber, na circulação, no tensionamento entre oferta e diferentes formas de apropriação, os fluxos das imagens fotográficas e o surgimento de certa remediação dessas imagens fotográficas.

\section{CONSIDERAÇÕES FINAIS}

Na observação da circulação, se pode encarar a comunicação como um sistema orgânico e a sociedade-organismo coerente e integrada com funções cada vez mais definidas com partes cada vez mais interdependentes. Além disso, a comunicação como gestão das relações complexas (comunicação turística, por exemplo) entre o centro dominante e a sua periferia. Para serem comunicadas as atrações e as paisagens notáveis fotografadas do meio rural, é preciso que elas estejam em circulação, em diferentes mídias e com distintas imagens fotográficas em evidência.

Percebe-se e analisou-se que é através das fotografias que muitas pessoas terão o primeiro contato com o local que pretendem conhecer. As fotografias despertarão curiosidade nos turistas levando-os à busca do conhecimento de determinado local ou não. Elas são vistas como componentes no processo de comunicação e interpretação e sem perceber, estão se inte- 
grando nas diferentes áreas das atividades humanas, dentre elas o turismo, tornando-as ferramentas intrínsecas para caracterizar uma localidade em sua forma mais íntegra, por meio de patrimônios tangíveis e intangíveis.

Sobre a mídia no turismo, lembra-se do poder da imagem que encanta e proporciona o desenvolvimento dessa atividade através dos meios de comunicação. Onde ocorre um processo de troca cultural e social entre as pessoas que se deslocam e se relacionam temporariamente fora de seu espaço em busca de novas experiências e conhecimentos. Com a finalidade de transmitir, passar a mensagem de alguém ou algum lugar, a comunicação junto à imagem reproduz as representações de ideias e impressões que cada pessoa tem em relação a um objeto em uma percepção anteriormente experimentada.

É necessário salientar, também, o quanto as mídias sofreram grandes transformações com a globalização, através da Internet, o indivíduo está sendo "bombardeado" por novas informações, novos conhecimentos e comportamentos. A Internet permite que as pessoas em suas casas, quando pensam em viajar, possam escolher o seu melhor destino turístico com maior facilidade e praticidade, através das imagens contidas nessa mídia. Diante disso, percebe-se o quanto é importante estudar essa circulação de imagens passando pela Internet.

A maneira como se pode analisar a circulação das fotografias tem relação direta, muitas vezes, com as intenções de produção, os anseios, os afetos que podem ser gerados, entre outros. Enquanto objetos, as fotos jamais poderiam circular como fazem hoje "imaterialmente", principalmente com a internet. Tal nível de abstração, próprio das novas mídias, incentiva outras práticas ou atos fotográficos, marcados pela visibilidade que a imagem captada pode assumir, para além de dimensões apenas privadas. Em rede, a fotografia, além de múltipla e heterogênea, torna-se potencialmente onipresente, podendo ser consumida na medida das conexões produzidas pelo "observador-operador".

Diante das análises, ficou evidente a implicação das mídias e das novas tecnologias sobre o setor turístico. Mais especificamente, as possibilidades advindas com o uso da Internet por este setor, que modificaram as relações entre os consumidores e produtores do setor turístico. Com estas novas tecnologias, o processo decisório de aquisição de produtos e pacotes turísticos é mais rápido, fazendo com que o planejamento da viagem e a decisão de onde viajar possam ser feitos através de suportes midiáticos. A grande dificuldade que surge em tal meio é justamente a de "encontrar o que se quer", 
tanto pela falta de imagens fotográficas de alguns atrativos, quanto pela grande quantidade de informações que circulam na Internet, das quais os tradicionais "buscadores" nem sempre conseguem dar conta com precisão. Ou mesmo pela dificuldade de se achar com precisão imagens fotográficas de algumas localidades, principalmente no meio rural.

Com relação ao que se espera para futuros trabalhos e contribuições, faz-se necessário a ampliação das discussões que envolvem a questão da motivação das viagens. Na verdade, é difícil de avaliar a natureza do turismo contemporâneo sem atentar para o fato de que tal atividade é construída, reforçada e "bombardeada" em nossa imaginação pelas mídias e pelos meios de comunicação. Sejam filmes, programas de televisão, cartões postais, redes sociais, Internet ou mesmo comerciais, estas são algumas das inúmeras possibilidades de se contemplar o mundo sem sair de casa que, no entanto, apenas ampliam e avivam nossos desejos e devaneios. A "vantagem" de ter todas essas informações ou mesmo o mundo dentro de casa, ao alcance de um toque, simplesmente estimula a busca por novas experiências e satisfações, ao contrário do que muitos podem pensar.

\section{REFERÊNCIAS}

BRAGA, J. L. La política de los internautas es producir circuitos: In: CARLÓN, M.; FAUSTO NETO, A. (orgs.) Las políticas de los internautas - nuevas formas de participación, Buenos Aires, La Crujía, 2012 (p. 43-59). [acesso a versão digitada cedida pelo autor]. 2012.

BRAGA, J. L. Os estudos de interface como espaço de construção do campo da comunicação. In: Grupo de Trabalho Epistemologia da Comunicação, XIII Compós, São Bernardo do Campo. 2004.

CASTANHEIRA, P. A inserção da atividade turística na exploração agropecuária. Turismo no espaço rural brasileiro. In: CONGRESSO BRASILEIRO DE TURISMO RURAL, 3. , 2001. Piracicaba/SP. Anais do $3^{\circ}$ Congresso Brasileiro de Turismo Rural. Piracicaba/SP: FEALQ. 2001.

EMBRATUR. Manual Operacional do Turismo Rural. Brasília/DF. 1994.

FAUSTO NETO, A. A Circulação além das bordas. In: fausto Neto, A \& Valdettaro, S. Mediatización, Sociedad y Sentido: Diálogos entre Brasil y Argentina. Rosário/Argentina: Departamento de Ciencias de la Comunicación - Universidad Nacional de Rosario. 2010.

FAUSTO NETO, A. Ensinando à TV Escola. João Pessoa, ed. UFPB. 2001.

FERREIRA, J. Dos objetos separados à circulação midiática como questão comunicacional. In: Fausto Neto, A.; et. al. (org.) Midiatização e processos sociais: aspectos metodológicos. Santa Cruz do Sul/RS: EDUNISC. 2010.

GÂNDARA, G. M. J. A imagem dos destinos turísticos urbanos. Revista eletrônica de 
turismo cultural. Recuperado em 23 de março de 2014, <www.eca.usp.br/turismocultural.> 2008.

GASTAL, S. Turismo, imagens e imaginários. São Paulo/SP: ALEPH - (Coleção ABC do Turismo). 2005.

PERINOTTO, A. R. C. Turismo Pedagógico: uma ferramenta para a educação ambiental. São Paulo. Recuperado em 04 de fevereiro de 2014, <http://www.cadernovirtualdeturismo.com.br/site/artigo/pdf.> 2008.

PERINOTTO, A. R. C. Circulação de Imagens Turísticas: Fotografias de Parnaíba/PI nas Mídias. São Leopoldo/RS; UNISINOS - Universidade do Vale do Rio dos Sinos. Programa de Pós-Graduação em Ciências da Comunicação. Tese de Doutorado. 2013 a.

PERINOTTO, A. R. C. Investigando a comunicação turística de Parnaíba/PI-Brasil: internet e redes sociais, descrição e análise. Revista de investigacion em turismo y desarrollo local TURyDES, vol 6, n 15 (dezembro 2013). Recuperado em 10 de março de 2014, <http://www.eumed.net/rev/turydes/15/parnaiba.pdf> 2013b.

SANTOS JÚNIOR, A. P; SANTOS, A. C. Arte e turismo: a fotografia como ferramenta de trabalho do turismólogo contemporâneo. $3^{\text {a }}$ Revista Eletrônica Aboré. Publicação da Escola Superior de Artes e Turismo. 2007.

SILVERSTONE, R. Mediação. In: Por que estudar a mídia? São Paulo/SP, Loyola. 2003. SONTAG, S. Sobre fotografia. São Paulo/SP: Companhia das Letras. 2004.

\section{André Riani Costa Perinotto}

Graduado em Turismo - BACHARELADO pela Universidade Metodista de Piracicaba (UNIMEP, 2002); ESPECIALISTA em Docência para Ensino Superior em Turismo e Hotelaria pelo SENAC/SP (2004); MESTRE em Geografia pela Universidade Estadual Paulista - UNESP/Rio Claro/SP (2006); DOUTOR em Ciências da Comunicação - UNISINOS/RS (2013). Foi aluno Especial de Doutorado do programa de Pós-graduação em Geociências e Meio-Ambiente da UNESP - 8 CRÉDITOS - 2007. Atualmente é Professor Adjunto do Curso de Bacharelado em Turismo da Universidade Federal do Piauí - UFPI, do campus Parnaíba. Atua principalmente com os seguintes temas: Turismo e Comunicação; Turismo e Educação; Turismo e Imagens; Turismo e Tecnologias; Produtos Turísticos. 